Received: 16.08.2020

Accepted: 21.04.2021

Published Online: 21.06 .2021

DOI: $10.18613 /$ deudfd.942958

Research Article
Dokuz Eylül University

Maritime Faculty Journal

Vol:13 Issue:1 Year: pp:149-181

ISSN: 1309-4246

E-ISSN: 2458-9942

\title{
DRY BULK AND GENERAL CARGO TERMINALS IN THE SUPPLY CHAIN: A DELPHI STUDY FOR ALIAGA
}

\author{
Gül DENKTAŞ ŞAKAR ${ }^{1}$ \\ Ali UZUN ${ }^{2}$
}

\begin{abstract}
Maritime transportation plays a vital role in the flow of various cargoes within a supply chain system. In this context, seaports have also started undertaking the provision of value-added services in the supply chain management, where logistics costs and service effectiveness are vital. Terminals that handle dry bulk cargoes which have low unit prices and high elasticity to transportation prices, and general cargoes that require different planning and management for almost each operation have significant roles in the chain as well. This study aims to determine and evaluate the role of dry bulk and general cargo terminals in the supply chain with the value-added logistic services by focusing on Aliağa Region. Delphi technique has been employed to shed light on the role of the dry bulk and general cargo terminals and manufacturers in the scope of supply-chain and logistics-based components. Findings indicate that service effectiveness is important as well as operational efficiency in such terminals and service characteristics should be improved to become more supply-chain oriented. Value-added services are considered as a differentiation factor where customers pay great attention.
\end{abstract}

Keywords: Supply Chain Management, Seaports, Dry Bulk Cargo Terminal, General Cargo Terminal, Value-added Logistic Services.

\footnotetext{
1 Assoc. Prof. Dr., Dokuz Eylül University, Maritime Faculty, gul.denktas@deu.edu.tr, orcid: 0000-0002-1072-6150

2 uzun.ali1@outlook.com, orcid: 0000-0001-8787-3223 (corresponding author)
} 


\title{
TEDARIKK ZINNCIRINDE KURU DÖKME VE GENEL YÜK TERMİNALLERİ: ALİAĞA İÇİN BİR DELPHI ÇALIŞMASI
}

\section{$\ddot{O} Z$}

\begin{abstract}
Denizyolu taşımacılı̆̆ tedarik zinciri sistemi içerisindeki çeşitli yük hareketlerinin gerçekleşmesinde önemli bir role sahiptir. Bu bağlamda; limanlar, lojistik maliyetlerin ve hizmet etkililiğinin hayati önem taşıdı̆̆ tedarik zinciri yönetiminde katma değer sağlama faaliyetini de üstlenmeye başlamışlardır. Düşük birim maliyete ve yüksek taşıma fiyatı esnekliğine sahip olan dökme yükleri ve neredeyse her operasyonunda farkl planlama ve yönetim gerektiren genel yükleri elleçleyen terminaller zincirde önemli bir yer edinmektedir. Bu çalışmada, kuru dökme ve genel yük terminallerinin sağladĭ̆ katma değerli lojistik hizmetler ve faaliyetler ile tedarik zinciri içerisindeki rolünün saptanması amaçlanmış ve değerlendirilmiştir. Aliağa Bölgesi'nde bulunan kuru dökme ve genel yük terminallerinin ve üreticilerin tedarik zinciri içerisindeki rolünü saptamak adına Delphi tekniği kullanılarak uzman görüşlerine başvurulmuştur. Çalışmanın bulgularl, bu tür terminallerde hizmet etkililiğinin en az operasyonel etkinlik kadar önemli olduğunu göstermiştir ve hizmetin özelliklerinin daha tedarik zinciri yönlü olmak için geliştirilmesi gerektiğini vurgulamaktadır. Katma değerli hizmetlerin bu tür terminallerde, müşterilerin özellikle önem verdiği farklılaştırıcı bir unsur olduğu da vurgulanmıştır.
\end{abstract}

Anahtar Kelimeler: Tedarik Zinciri Yönetimi, Liman, Kuru Dökme Yük Terminali, Genel Yük Terminali, Katma Değerli Lojistik Hizmetler.

\section{INTRODUCTION}

Nowadays, competition between companies leaves its place to competition between supply chains. The main reason is that supply chain management targets the maximum output with the minimum input by carrying out the whole process with all process participants in coordination and cooperation. Today, ports have roles such as transshipment center, distribution center, and logistics center by not only transferring cargoes between sea and land but also providing various logistics services and activities (Güneş and Esmer, 2016). One of the reasons of change is that ports aim to increase customer satisfaction and thus their income and performance as being part of the supply chains (Robinson, 2002; KarataşÇetin and Cerit, 2014). Shifts exists in the roles and missions with the use of outsourcing in the supply chain management, where logistics costs and service effectiveness are vital. These outsourcing strategies result from the possibility of conducting various logistics activities more efficiently in the ports that have the requirements to become logistics centers and have sufficient infrastructure, superstructure, area, equipment and labor. In 
addition, ports have become suitable for having a role in almost all logistics processes by providing services such as inland transportation, and storage support.

The role of dry bulk and general cargo ports in the supply chain is mostly involved in the supply process of the chain. Bulk cargo terminals are mainly involved in the transfer of raw materials in homogeneous form, so these terminals are more likely to be between the raw material suppliers and manufacturers processing these raw materials. General cargo terminals have a role in the transfer of the semi-finished and finished products, so that the general cargo terminals can mostly be between the semi-finished goods manufacturers, finished goods manufacturer, wholesalers and even in the other stages extending to the end user (Esmer and Karataş Çetin, 2016; Alderton, 2008; Frankel et al., 1984). In addition, bulk and general cargo terminals have the role of cross-docking distribution facility. Bulk cargo terminals combine cargoes that are collected from different raw material suppliers and transfer these cargoes to the manufacturers. General cargo terminals ensure that the cargoes collected from the manufacturers as a whole are distributed to different customers in the chain (Alderton, 2008; Rodrigue, 2020). Finally, a typical port can both have a dry bulk cargo and a general cargo terminal. Thus, it can take place in both the supplying and distribution stages of the process (Frankel et al., 1984). In fact, there is not much difference between dry bulk and general cargo terminals in practice since similar equipment is needed. For example, a harbour crane can handle both dry bulk and general cargoes thanks to different attachments. Dry bulk and general cargo terminals provide valueadded logistic services in addition to the core activities in order to meet the needs of the supply chain and satisfy its customers. These value-added services can be classified as storage, quality control, testing, packaging, assembly, repair and maintenance, track and trace, lashing and securing, inland transportation, providing information flow, and there are some value-added activities such as trailer renting, parking, etc. (Tuna and Arabelen, 2016: 555; Karataş Çetin, 2011: 28). Most of these value-added services and activities might be realized not only by the port operators, but also by third-party service providers who have a contractual relationship with the port business.

The objective of this paper is to determine the role of the port businesses, that handle dry bulk and general cargoes, in the supply chain with the value-added services and activities they provide. In this context; the competencies that can meet the supply chain needs have been examined, the efficiency and effectiveness of the value-added services provided by these port businesses have been analysed, the transportation infrastructure of the region (Aliağa as the scope of the study) has been evaluated, and suggestions and recommendations have been collected from 
the experts in order to strengthen the role of these port businesses in the supply chains through Delphi technique. Aliağa Region, located in western coast of Turkey, has an important role in the industry and trade. Port businesses which handle dry bulk and general cargoes in Aliağa, are involved in the import of raw materials and semi-finished products required for the industrial activities provided in the region, and the export of semi-finished and finished products collected from manufacturers to their customers are evaluated regarding to their role in the supply chain.

\section{LITERATURE REVIEW}

Logistics and supply chain perspectives focus on the integrative nature of different processes of a company which extends to a wider network of organizations aiming to achieve cost reduction and customer satisfaction (Stank et al., 2001). Cost trade-off approach is widely employed between functions, processes and supply chain systems (Rushton et al., 2000). Bichou and Gray (2004) purported that similar approach can also be used in the port strategy formulation by focusing on value-added logistics services since there has been a radical change in the role of ports considering the latest changes in logistics and supply chain systems. While seaports were only viewed as the locations of handling for import and export cargoes before, such traditional role has changed switching ports from traditional centers of loading and discharging cargoes to transshipment and logistics centers (UNESCAP and KMI, 2005). Seaports are also considered as inland logistics centers since they are nodal points integrating different segments of inland transportation system such as road/rail, road/road, rail/rail (UNCTAD, 2004).

Seaports have become a key component of supply chain systems. They are considered as critical economic areas that provide various services to customers such as shippers, freight forwarders, carriers, logistics service providers etc. Relevant literature on seaports, logistics and supply chain management reveals the role of seaports as critical component of distribution systems (Bichou and Gray, 2004). Much of the literature reviews on seaports concentrates on the increasing importance of ports as strategic nodal points in the logistics and supply chains systems (Behdani et al., 2020; Garcia-Alonso et al., 2017; Haralambides, 2017; Min and Jun, 2014; Panayides, 2006; Bichou and Gray, 2004; Paixao and Marlow, 2003; Carbone and De Martino, 2003; Robinson, 2002).

In the light of such dramatic changes in the roles of the ports as well the environment that they are operating in, services provided by the ports and their competitive strategies have also been re-considered and modified. According to Notteboom and Winkelmans (2004), seaports should create core competencies and economies of scope by taking an active role in the 
development of port-related value-added services, information systems and intermodal transport services. Robinson (2002) introduced port value chain concept and viewed ports as components embedded in value-driven chain systems providing value to shippers and other third-party service providers. There is an increasing competition among seaports to differentiate their services by providing value-added services and intermodal transport services (Verhoeven, 2010). Globalisation has also triggered ports to provide value-added services and enabled ports to experience a transformation process from a traditional sea-land interface to centers of logistics networks and value-added services (Bichou and Gray, 2005). Song and Panayides (2008) listed technology, value-added services, the relationship with customers and liner shipping companies, the facilitation of intermodal transport and channel integration practices as the critical factors that affect port/terminal integration in supply chains. As seen in the related literature, there are plenty of studies concentrating on port-supply chain integration, logistics implications of ports and emerging service scope of ports such as value-added services and intermodal transport services.

According to Esmer and Karataş Çetin (2016), ports can operate as industrial centers, where there are intermodal transportation connections and distribution centers and production and industrial activities are carried out. Ports have become an integral part of the supply chain in management and coordination of material and information flow (Esmer, 2010; Panayides and Song, 2008; Robinson, 2002). In this context; ports aim to be parts of the supply chains by providing various value-added services in addition to their core activities such as handling, warehousing, and sheltering. In addition, Esmer (2010) refers the changes of ports from being a simple transfer points traditionally to logistics centers as an evolution. According to Mangan et al. (2008), some of the reasons of this evolution are the port centric logistic practices and supply chain strategies. The concept of port centric logistics is a system beyond a facility, this system should be in coordination with supply chain strategies; and according to these strategies, ports are transformed into facilities such as transshipment center, logistics center, and distribution center (Güneş and Esmer, 2016). The ports that are integrated with the concept of port centric logistics become available to be the center of the supply chain by providing various value-added services which are integrated with the supply chain and can meet the needs of the members in the chain (Chairany and Hidayatno, 2019).

Despite an increasing focus on such emerging services provided by ports as well as supply chain orientation practices, current literature heavily focuses on container transport and container terminals and overlooks capability of ports to become logistics centers for dry bulk and general 
cargoes as well. In addition, value-added services capabilities of ports are widely discussed from the perspective of containerized shipments in the relevant literature (Pettit and Beresford, 2009; Song and Panayides, 2008; De Martino and Morvillo, 2008). Studies that are related with the dry bulk and general cargo terminals within the scope of value-added services are very limited, and their role in the supply chain needs to be determined. Lee et al. (2014) and Balc1 et al. (2018) also addressed such limitation in the studies about dry bulk terminals. Although value-added perspective of dry bulk and general cargo terminals is widely neglected in the current literature, there are diversified topics on such terminal types studied by scholars in the field.

Schott and Lodewijks (2007) explored the main areas for the development of bulk terminals by focusing on handing, storage and processing of bulk cargoes within Le Havre-Hamburg region. From Turkey's perspective, Bal and Esmer (2015) investigated operational processes in liquid bulk terminals. Balci et al. (2018) discussed the competition between dry bulk terminals and concluded that although dry bulk terminal selection criteria are similar to container terminal selection criteria, the importance rankings were found different. Vast body of literature concentrated on the design and operational planning of bulk terminals (Ünsal and Oğuz, 2019; de Leòn et al., 2017; Yang et al., 2017; Babu et al., 2015; van Vianen et al., 2014; Lodewijks et al., 2007; Barros et al., 2011). For instance, Ünsal and Oğuz (2019) focused on planning problem of dry bulk terminals in case of three problem areas of berth allocation, reclaimer-scheduling and stockyard allocation. Similarly, reclaimer scheduling ( $\mathrm{Hu}$ and Yao, 2012), berth allocation (Ernst et al., 2017; de Leòn et al., 2017; Barros, 2011), stockyard size planning (van Vianen et al., 2014), reduction of delays (Sayareh and Ahouei, 2013). From a different perspective, Dinwoodie et al. (2014) synthesized the perceptions of experts regarding trends in dry bulk shipping activities to 2050. However, to the best of authors' knowledge, no study has specifically discussed the role of dry bulk and general cargo terminals in terms of value-added activities.

Although logistics of raw materials and semi-finished products is very important especially in the developing countries such as Turkey; evaluation of bulk and general cargo terminals in terms of logistics and supply chain management, and analysis of the value-added services provided in these terminals are neglected in the previous studies. Hence, this study has been conducted to shed light on the current situation of dry bulk and general cargo terminals by concentrating on a specific region, namely Aliağa Region. This has been achieved by considering logistics and supply chain perspectives which are specific for port organizations. As the case in this study, Aliağa Region has a density of industrial activities, 
and the terminals in the region act as distribution centers to provide material flow between manufacturers and their customers. This study can be considered as an original research with a narrower scope by focusing on bulk and general cargo terminals with the case of Aliağa Region.

Details regarding the application of Delphi study, questionnaire development sampling criteria and data collection are explained in the following section.

\section{METHODOLOGY: THE DELPHI TECHNIQUE}

Exploratory Delphi study is employed for shedding light on the role of dry bulk and general cargo terminals by considering logistics and supply chain components. Delphi technique is defined as an instrument of collecting and refining group opinions through a series of questionnaires (Kinnear and Taylor, 1996). Delphi technique allows researchers to receive input from a larger sample (panel of experts) than other group meetings and from members who are geographically dispersed (Rowe and Wright, 1999). Delphi technique is formed by applying series of questionnaires to obtain the most reliable consensus from a group of experts with controlled opinion feedback (Dalkey and Helmer, 1963). In addition, the use of Delphi method is convenient for exploring the current research field by obtaining opinions leading to different judgements from a group of experts (Turoff, 1970). The Delphi technique is a method where a series of rounds are conducted with the participation of experts, mostly through a survey consisting of a series of rounds with questionnaires (Fontana and Frey, 1994). Experts are asked to make judgments or to comment on the items presented. Each subsequent questionnaire builds upon responses to the previous questionnaire. Completed questionnaire of the first round is analysed to determine the status of agreement and disagreement. In the light of the feedback received from participants, new statements are designed and the opinions of the experts are in the second round of the research. The process is terminated when consensus is reached among participants.

The Delphi study is considered appropriate for this study because there are various participants in seaports and when supply chains perspective is also considered together with dry bulk and general cargo focus, it has been agreed that consensus is needed with regards to the characteristics of such terminals. The role of the dry bulk and general cargo terminals in the supply chain with the value-added services is not previously analysed in Aliağa Region. Thus, the use of Delphi technique is more suitable rather than other qualitative research methods such as interviews in order to obtain different opinion from various supply chain participants. When literature review was conducted, it was observed 
Delphi research was employed in various studies from the different perspectives of maritime transport. Topics ranged from maritime container port security (Zhang and Roe, 2019), potential benefits of short sea shipping in Southeast Asia sub region (Arof et al., 2016), similarly British coastal shipping (Saldanha and Gray (2002) to the potential for the clustering of maritime transport sector in the Greater Dublin (Brett and Roe, 2010), development of multimodal transport (Islam et al., 2006) conflict issues in combined transport (Deveci and Cerit, 2007), marine salvage services (Atik and Cerit, 2008) to transport and logistics developments in Baltic Sea Region (Ojala et al., 2013) and forecasting in dry bulk shipping flows (Dinwoodie et al., 2014).

The main advantages of the Delphi method can be listed as; (i) experts are not under pressure and can generate their own opinions independently, (ii) there are not interpersonal conflicts and communication problems since there is no interaction between the participants, (iii) time and cost problems are eliminated because there is no obligation for meeting at a single time and place (iv) anonymity. Anonymity is established when participants are contacted by e-mail and invited to complete the questionnaire. Since there is no face-to-face encounter of participants, they do not feel pressure originating from dominant participants and the bandwagon effect encouraging agreement with the majority is decreased (Fadda, 1996). Thus, the use of Delphi method has provided such advantages especially when the existence of competing companies in the region is considered. The technique has allowed the researchers to get opinions of competing companies without any interaction with each other. Delphi method, which aims to obtain different opinions from various actors, consist of some stages as shown in Figure 1. All the steps are explained in detail at following sub-sections.

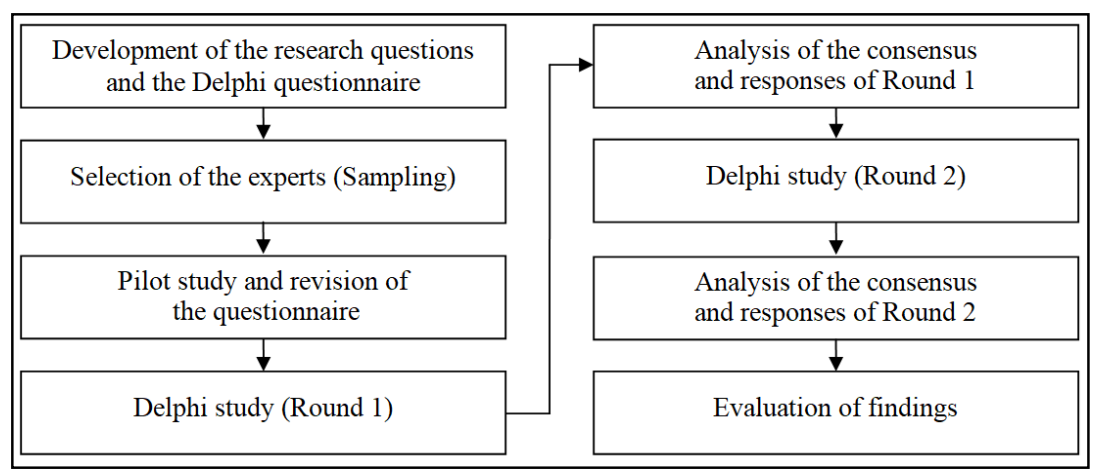

Figure 1: Stages of the Delphi Study 


\subsection{Questionnaire Development}

Questionnaire development which is the first step of the Delphi study is a key stage to achieve a valid, reliable, and utilizable research. Since the literature on the role of dry bulk and general cargo ports in the supply chain management is limited, a standard questionnaire was not used directly or obtained from another research. The statements in the questionnaire were generated by adapting some dimensions and components from the relevant literature on supply chain, logistics and dry bulk and general cargo terminals. As it is shown in Table 1, the statements in the questionnaire were organized under two headings as; supply chainport related and logistics-port related.

Table 1: Sections in the Questionnaire

\begin{tabular}{|l|l|}
\hline \multicolumn{1}{|c|}{ Supply Chain-Port Related } & \multicolumn{1}{c|}{ Logistics-Port Related } \\
\hline Degree of Integration & Operational Efficiency versus Service Effectiveness \\
\hline Providing Information Flow & Hinterland Transportation Infrastructure \\
\hline Requirements to Meet Supply Chain Needs: & Use of Railway and Road Transportation \\
\hline Infrastructure & Organization of Logistics Activities: \\
\hline Superstructure & Transportation, Warehousing \\
\hline Equipment & Track and Trace \\
\hline Labor & Safety \\
\hline Degree of Technological Development & Providing Value-Added Services \\
\hline
\end{tabular}

Source: Adapted from Garcia-Alonso et al., 2017; Güneş and Esmer, 2016; Bal and Esmer, 2015; Song and Panayides, 2012; Esmer, 2010; Mangan et al., 2008; Song and Panayides, 2008; Panayides and Song, 2007

Supply chain-related statements aim to measure degree of integration between terminals and the port users which are the main requirements in a successful supply chain. As Panayides and Song (2007) dictated, high level of coordination, integration and connectivity are the main requirements for an efficient port logistics system. Providing information flow which is the most critical flow in the supply chain; degree of requirements to meet needs of the supply chain as; infrastructure, superstructure, equipment, and labor; and degree of technological development which affects the operational efficiency and service quality are also listed.

Logistics-related statements include basic components related to (i)operational efficiency which aims to minimize the inputs and maximize the outputs and service effectiveness which consists of flexibility, reliability etc. (Song and Lee, 2009; Song and Panayides, 2012) (ii) status of hinterland transportation infrastructure and comparison of road and railway transport options (iii) organization of logistics activities such as 
warehousing, transportation, tracking and tracing (iv) safety of cargoes and ships and (v) the degree of the efficiency, effectiveness, and existence of the value-added services that are provided by terminals in the region.

Questionnaire aims to analyse the role of dry bulk and general cargo terminals in the Aliağa Region by defining existing services and activities, focusing on the efficiency and effectiveness of these activities within supply chain processes, and understanding the requirements for a successful supply chain for the region. All the statements in Delphi study both for round 1 and round 2 are shown in Table 3 and Table 4 in the findings section. In addition to the statements in the Delphi study, two open-ended questions were asked to the participants at the end of the firstround questionnaire. The first open-ended question aims to identify the most demanded value-added services in dry bulk and general cargo ports. The second open-ended question aims to indicate the requirements to strengthen the role of dry bulk and general cargo ports within the supply chain system in Aliağa Region. The purpose of these open-ended questions is to give free space to participants by collecting more information and opinions. Since this study has an exploratory nature by focusing on an area where there is very limited research, such open-ended questions are expected to provide more room for additional ideas and perspectives. The answers were evaluated in the findings section.

\subsection{Sampling, Scope of the Study and Data Collection}

The Delphi sample is not considered as a random expert sample since it is aimed to include the main important parties in dry bulk and general cargo businesses. The main determinants for the selection of experts can be listed as; certain level of experience in the industry, awareness of the supply chain management and port business, and willingness to share his/her ideas for the research. These are the requirements for a successful Delphi study.

As sampling methods employed in this research, purposive and snowball sampling enabled researchers to reach experienced participants in a convenient way. Purposive sampling is a non-probability sampling technique which is preferred when one needs to make a research on a specific field with knowledgeable experts (Creswell, 2005; Polit and Hungler, 1997). In addition, snowball sampling was employed and participants made suggestions to the researchers regarding other potential experts who could contribute to the study (Skulmoski, et al., 2007). In order to reflect important outcomes from the Delphi study, it was decided to include experts from industries such as; port businesses, shipping companies, manufacturers and academia. As Czinkota and Ronkainen (1997) stated, panel selection should be conducted to ensure that 
knowledgeable and experienced people should be present in order to represent multidisciplinary stakeholder views in Delphi studies. There is no established rule for determining the appropriate sample size (Loo, 2002; Williams and Webb, 1994). Hsu and Sandford (2007) purported that the size of the sample at Delphi research might vary and the number of experts involved in many Delphi studies might range from 15 to 20 (Ludwig, 1997). Gordon (1994) pointed out that Delphi research could be conducted with 10 or more participants. Also, possible sizes of Delphi studies are suggested as no less than 8 to 10 (Scapolo and Miles, 2006). Port business studies in the scope of Delphi research were reviewed. Some examples from sample sizes in port business studies that employed Delphi research can be given as; 14 experts (Göçer et al., 2019); 13 experts (Tezcan and Kuleyin, 2019), 43 experts (Alghaffari et al., 2018), 46 participants (Chen and Pak, 2017); 14 experts (Altuntaş Vural et al., 2015), 12 participants (Emiroğlu and Özer Çaylan, 2014); 22 experts (Da Cruz et al., 2013), and 8 experts (Karataş Çetin and Cerit, 2010). As Karataş Çetin and Cerit (2010) pointed out, port business is a unique area and there are limited number of experts with sufficient time to contribute to such studies. Since Aliağa Region is a niche business district with limited number of terminals providing dry bulk and general cargo services, the availability and the number of participants is also limited. This study is conducted by focusing on Aliağa Region and the participants are selected to represent such businesses in the Delphi study. As Skulmoski et al. (2007) pointed out a homogeneous group may need a smaller sample of 10 to 15 participants. This is reflected in the sampling of the study that a limited number of experts within a niche area was selected. Table 2 shows the details regarding the experts in the study. 
Table 2: Profile of the Participants

\begin{tabular}{|c|c|c|c|}
\hline \begin{tabular}{|l|} 
Industry \\
\end{tabular} & Number & Position & Number \\
\hline Port Business & 6 & Shift Supervisor & 6 \\
\hline Maritime Transportation & 1 & Broker & 1 \\
\hline \multirow{2}{*}{ Steel Industry } & \multirow{2}{*}{2} & Warehouse Supervisor & 1 \\
\hline & & Shipping Supervisor & 1 \\
\hline Academia & 1 & Professor in Shipping & 1 \\
\hline $\begin{array}{l}\text { Experience in the institution } \\
\text { at present }\end{array}$ & Number & Level of Education & Number \\
\hline Less than 5 Years & 8 & \multirow{2}{*}{ Undergraduate } & \multirow{2}{*}{7} \\
\hline 5-10 Years & 2 & & \\
\hline $\begin{array}{l}\text { Total Experience in the } \\
\text { Industry }\end{array}$ & Number & \multirow[t]{2}{*}{ Postgraduate } & \multirow[t]{2}{*}{2} \\
\hline Less than 5 Years & 3 & & \\
\hline 5-10 Years & 6 & \multirow{2}{*}{ Doctorate } & \multirow{2}{*}{1} \\
\hline 16-20 Years & 1 & & \\
\hline
\end{tabular}

As shown in Table 2; there are 6 participants from the port businesses, 1 participant from a maritime transportation company, 2 participants from steel manufacturing, and 1 participant from academia. Considering their position in the industry, 5 participants are shift supervisors, 1 is broker, 1 is warehouse supervisor, 1 is shipping supervisor and 1 is professor in shipping. In the study, both the participants' total experience in the industry and their experience in the institution they are currently working at have been asked to the participants. In this context, $80 \%$ of the participants have less than 5 years of experience in the institution where they work, and $60 \%$ of them have between 5-10 years of total experience in the industry. Finally, on the basis of the education levels of the participants, 7 participants completed the undergraduate degree, 2 participants graduate degrees, and 1 participant doctorate.

The scope of the study is considered as the general and dry bulk cargo terminals in Aliağa Region. Izmir can be considered as one of the main port regions where dry bulk terminals are located close to each other (Balc1 et al., 2018). In scope of dry bulk and general cargoes, two main ports are available as the Port of Izmir (government port) and terminals in Aliağa Region-Nemrut Bay. Aliağa Region, located in the Aegean Region of Turkey, comprises of many industrial facilities such as refinery, petrochemical plant, fertilizer factory, paper and cellulose factory, ship demolition facility, steel factories that have been established since 1960s (Eroğlu and Bozyiğit, 2013). Terminals are needed for the transportation of cargo by sea transport in the Aliağa Region, where industrial and commercial activities are dense. Port of Aliağa, which is the third biggest port based on amount of cargo handled in Turkey in 2019, has the terminals 
that handle dry bulk cargoes, liquid bulk cargoes, general cargoes, and containers (DTGM, 2020). Due to the clustering of industrial activities in the region, cargoes handled in the region are mainly composed of industrial products, especially for the cargoes handled at the bulk terminals. There are 7 port businesses that handle dry bulk and general cargoes in the Aliağa Region. These are Ege Gubre, Batıcim, Izmir Demir Celik Sanayi A.S., Ege Celik, Habas, Petkim, and Nemport port businesses (Türklim, 2018). Many of these port businesses are the parts of the group companies of industrial firms operating in the Aliağa Region. In addition, these port businesses provide services to other enterprises.

Due to a constraint caused by a pandemic called COVID-19 during the data collection process, it has been determined that face-to-face data collection posed a risk to both participants and the researchers, so that the data collection process has been realized by sending an online survey link to the participants via e-mail and LinkedIn account. Firstly, all the participants' details regarding their title, company, e-mails and phone/mobile numbers were obtained by the researchers. Since snowball sampling was also employed in the study, contact details were obtained from other experts as well. Authors contacted the experts via phone calls, e-mails and messages to their LinkedIn accounts in order to inform the experts about the study and ask for their consent in the cover letter to participate Delphi study. Similar approaches have also been employed by other scholars in order to reach the experts through the use of e-mail and phone calls (Göçer et al., 2019; Denktaş Şakar et al., 2018; Altuntaş Vural et al., 2015; Emiroğlu and Özer Çaylan, 2014; Ojala et al., 2013; Karataş Çetin and Cerit, 2010). Two different survey links were sent to the experts who accepted to participate in the study within the time intervals stated below for the first round and the second round via email and LinkedIn. Then the answers collected were tabulated using Excel by authors. The first round of the Delphi study started on April 20, 2020 and ended on May 4, 2020. During this period, 15 participants had been contacted, however, the final number of participants in the first round were 10 due to COVID- 19 period, busy schedules and some other personal excuses. The response rate for the first round of the Delphi study is 67\%. After the analysis of the consensus and responses of the first round had been completed, statements that reached consensus were re-formulated for the second round. The second round of the Delphi study started on May 6, 2020 and ended on May 18, 2020. The second-round questionnaire had been directed to 10 experts who participated in the first round, and 9 of them participated in the study. The response rate in the second round of the Delphi study was $90 \%$. After the second round had been completed; the responses had been re-analysed and it was seen that consensus was reached in all statements, so the data collection period was finalized. 


\subsection{Validity and Determination of Consensus}

The validity of the study can be evaluated by considering the suggestion in the related literature made by Fink et al. (1984), Murphy et al. (1998). Suitability of the method used for meeting the aim of the study and addressing the problem, the condition of being experienced and having adequate knowledge about the research in the selection of experts, explaining of the steps of the study; especially steps of questionnaire development, data collection and evaluation of findings, and providing justifiable consensus levels can be considered basic components for achieving the validity of the study (Fink et al., 1984; Murphy, et al., 1998). In addition, a pilot survey had been conducted following the questionnaire development for the first round of the Delphi study with two experts who are experienced in the logistics and port industry to increase validity and reliability of the study. These experts made necessary changes in the wording of the statements in the Delphi study and such feedback helped authors to revise the statements to be used in the first round of the study.

Determination of consensus and quantification of its degree is another topic to be considered in Delphi research that subjective criteria or descriptive statistics were employed in many studies where Delphi method is used (Von der Gracht, 2012). The consensus rate is critical in a Delphi study since defining the statements as consensus is a requirement for evaluating them appropriate in findings. There is not a standard consensus rate agreed commonly in the literature (Denktaş Şakar and Marlow, 2009). There are Delphi studies where the consensus rate is defined as $51 \%, 70 \%$ and 80\% (Goodrich, 1982; Hasson, et al., 2000; Atik and Cerit, 2008; Denktaş Şakar et al., 2018). In this study, the consensus rate has been determined $70 \%$ which is equal to or higher than the consensus rates used by Goodrich (1982), Islam et al. (2006). Finally, the statements consist of three answer options as "agree", "disagree", and "unable to comment" in the questionnaire. The same answer options have been used by Goodrich (1982), Islam, et al. (2006), Deveci and Cerit (2007), Atik and Cerit (2008), Denktaş Şakar and Marlow (2009), Denktaş Şakar, et al. (2018), Gocer et al. (2019).

\section{FINDINGS}

Findings consist of two main categories which are supply chain-port related statements and logistics-port related statements in the Delphi study. All the statements and opinions of experts are shown in Table 3 for the first round, and in Table 4 for the second round. As shown in the tables, there are there answer options as "agree", "disagree", and "unable to comment". "N" refers to number of experts that agree with any opinion. The rates in 
the answers refer to the agreement rate with the formula of "number of agree or disagree / number of totals agree and disagree * 100 ". If this rate is $70 \%$ and above, consensus is achieved for this statement. If not, the statement is reformulated for the next round. All the statements have been numbered and shown in parentheses at the end of the sentences, for example (S1) refers to first statement in the Table 4.3; and if it is revised for the second round, it is shown as (S1.1).

The existence of manufacturers and port businesses within the group of companies in the Aliağa Region increases the integration and chain efficiency (S1), and providing information flow between the terminals and the manufacturers in the hinterland is important in terms of supply chain efficiency (S2). Port businesses handling dry bulk and general cargoes in the Aliağa Region have sufficient infrastructure, superstructure, equipment, and labor to meet the needs of chain participants and to serve other parties (S3, S4, S5, S6). Human resources are sufficient to manage the supply chain processes in the logistics of the industrial cargoes in the Aliağa Region (S7). According to $50 \%$ of the experts, terminals in the Aliağa Region does not follow technological developments at a sufficient level. Since there was no consensus on this statement, this was considered in the second round of the study. According to second round findings, terminals located in the Aliağa Region should pay more attention to technological developments in order to increase operational efficiency and service quality with the consensus rate of $100 \%$ (S8.1). Bulk cargo terminals are one of the important nodes between raw material suppliers and manufacturers in supply chains (S9). Collecting raw materials from different chain participants at the bulk terminals and transferring them to the manufacturers has turned the bulk cargo terminals into a crossshipment facility and strengthened its position in supply chains (S10). 
Table 3: Results of the First Round of the Delphi Study

\begin{tabular}{|c|c|c|c|c|c|c|}
\hline \multirow{3}{*}{ Delphi Statements } & \multicolumn{5}{|c|}{ Answers } & \multirow{3}{*}{$\begin{array}{c}\text { Consensus } \\
\text { Status }\end{array}$} \\
\hline & \multicolumn{2}{|c|}{ Agree } & \multicolumn{2}{|c|}{ Disagree } & \multirow{2}{*}{\begin{tabular}{|c|}
$\mathbf{U C}$ \\
$\mathbf{N}$ \\
\end{tabular}} & \\
\hline & $\mathbf{N}$ & Rate & $\mathbf{N}$ & Rate & & \\
\hline $\begin{array}{l}\text { S1. The existence of manufacturers and } \\
\text { port businesses within the group of } \\
\text { companies in the Aliaga Region increases } \\
\text { the integration between them and chain } \\
\text { efficiency }\end{array}$ & 10 & $100.0 \%$ & $\mathrm{O}$ & $0.0 \%$ & o & $\begin{array}{c}\text { Consensus } \\
\text { (A) }\end{array}$ \\
\hline $\begin{array}{l}\text { S2. Providing information flow between } \\
\text { the terminals in the Aliağa region and the } \\
\text { manufacturers in the hinterland is not at } \\
\text { the forefront in terms of supply chain } \\
\text { efficiency. }\end{array}$ & 1 & $10.0 \%$ & 9 & $90.0 \%$ & O & $\begin{array}{c}\text { Consensus } \\
\text { (DA) }\end{array}$ \\
\hline $\begin{array}{l}\text { S3. Port businesses handling bulk and } \\
\text { general cargoes in the Aliaga region have } \\
\text { sufficient infrastructure to meet the needs } \\
\text { of chain participants and to serve other } \\
\text { parties. }\end{array}$ & 8 & $88.9 \%$ & 1 & $11.1 \%$ & 1 & $\begin{array}{c}\text { Consensus } \\
\text { (A) }\end{array}$ \\
\hline $\begin{array}{l}\text { S4. Port businesses handling bulk and } \\
\text { general cargoes in the Aliağa region have } \\
\text { sufficient superstructure to meet the } \\
\text { needs of chain participants and to serve } \\
\text { other parties. }\end{array}$ & 7 & $77.8 \%$ & 2 & $22.2 \%$ & 1 & $\begin{array}{c}\text { Consensus } \\
\text { (A) }\end{array}$ \\
\hline $\begin{array}{l}\text { S5. Port businesses handling bulk and } \\
\text { general cargoes in the Aliağa region have } \\
\text { sufficient equipment to meet the needs of } \\
\text { chain participants and to serve other } \\
\text { parties. }\end{array}$ & 9 & $100.0 \%$ & $\mathrm{O}$ & $0.0 \%$ & 1 & $\begin{array}{c}\text { Consensus } \\
\text { (A) }\end{array}$ \\
\hline $\begin{array}{l}\text { S6. Port businesses handling bulk and } \\
\text { general cargoes in the Aliağa region have } \\
\text { sufficient labor to meet the needs of chain } \\
\text { participants and to serve other parties. }\end{array}$ & 10 & $100.0 \%$ & $\mathrm{O}$ & $0.0 \%$ & o & $\begin{array}{c}\text { Consensus } \\
\text { (A) }\end{array}$ \\
\hline $\begin{array}{l}\text { S7. In the logistics of the industrial } \\
\text { cargoes in Aliaga region (raw materials } \\
\text { such as coal, scrap; and semi-finished and } \\
\text { finished products such as steel profiles, } \\
\text { billets), human resources are sufficient to } \\
\text { manage the supply chain processes. }\end{array}$ & 8 & $80.0 \%$ & 2 & $20.0 \%$ & o & $\begin{array}{c}\text { Consensus } \\
\text { (A) }\end{array}$ \\
\hline
\end{tabular}


Table 3: Results of the First Round of the Delphi Study (Cont.)

\begin{tabular}{|c|c|c|c|c|c|c|}
\hline \multirow{3}{*}{ Delphi Statements } & \multicolumn{5}{|c|}{ Answers } & \multirow{3}{*}{$\begin{array}{l}\text { Consensus } \\
\text { Status }\end{array}$} \\
\hline & \multicolumn{2}{|c|}{ Agree } & \multicolumn{2}{|c|}{ Disagree } & \multirow{2}{*}{\begin{tabular}{|c|}
$\mathbf{U C}$ \\
$\mathbf{N}$ \\
\end{tabular}} & \\
\hline & $\mathbf{N}$ & Rate & $\mathbf{N}$ & Rate & & \\
\hline $\begin{array}{l}\text { S8. Terminals in Aliağa region follow } \\
\text { technological developments at a } \\
\text { sufficient level. }\end{array}$ & 5 & $50,0 \%$ & 5 & $50,0 \%$ & 0 & $\begin{array}{l}\text { Second } \\
\text { Round } \\
\text { Applied }\end{array}$ \\
\hline $\begin{array}{l}\text { S9. Bulk cargo terminals are one of the } \\
\text { important nodes between raw material } \\
\text { suppliers and manufacturers in supply } \\
\text { chains. }\end{array}$ & 10 & $100,0 \%$ & 0 & $0,0 \%$ & 0 & $\begin{array}{l}\text { Consensus } \\
\text { (A) }\end{array}$ \\
\hline $\begin{array}{l}\text { S10. Collecting raw materials from } \\
\text { different chain participants at the bulk } \\
\text { terminals and transferring them to the } \\
\text { manufacturers has turned the bulk cargo } \\
\text { terminals into a cross-shipment facility } \\
\text { and strengthened its position in the supply } \\
\text { chain. }\end{array}$ & 9 & $100,0 \%$ & 0 & $0,0 \%$ & 1 & $\begin{array}{l}\text { Consensus } \\
\text { (A) }\end{array}$ \\
\hline $\begin{array}{l}\text { S11. In bulk logistics, operational } \\
\text { efficiency is more important than service } \\
\text { effectiveness. }\end{array}$ & 3 & $33,3 \%$ & 6 & $66,7 \%$ & 1 & $\begin{array}{l}\text { Second } \\
\text { Round } \\
\text { Applied }\end{array}$ \\
\hline $\begin{array}{l}\text { S12. The hinterland road transportation } \\
\text { infrastructure is not at sufficient level in } \\
\text { the Aliağa Region. }\end{array}$ & 4 & $44,4 \%$ & 5 & $55,6 \%$ & 1 & $\begin{array}{l}\text { Second } \\
\text { Round } \\
\text { Applied }\end{array}$ \\
\hline $\begin{array}{l}\text { S13. The hinterland railway infrastructure } \\
\text { is at sufficient level in the Aliağa Region. }\end{array}$ & 0 & $0,0 \%$ & 10 & $100,0 \%$ & 0 & $\begin{array}{l}\text { Consensus } \\
\text { (DA) }\end{array}$ \\
\hline $\begin{array}{l}\text { S14. The use of rail transportation is } \\
\text { more efficient than road transportation in } \\
\text { domestic transportation of bulk cargoes } \\
\text { with short distances between } \\
\text { manufacturers and bulk cargo terminals. }\end{array}$ & 2 & $20,0 \%$ & 8 & $80,0 \%$ & 0 & $\begin{array}{l}\text { Consensus } \\
\text { (DA) }\end{array}$ \\
\hline $\begin{array}{l}\text { S15. Organizing the inland transportation } \\
\text { activities by the port business is a service } \\
\text { that reduces efficiency. }\end{array}$ & 3 & $30,0 \%$ & 7 & $70,0 \%$ & 0 & $\begin{array}{l}\text { Consensus } \\
\text { (DA) }\end{array}$ \\
\hline $\begin{array}{l}\text { S16. In the transportation of bulk cargoes, } \\
\text { it is more efficient to track and trace the } \\
\text { load flow between the manufacturers and } \\
\text { the port by port businesses rather than } \\
\text { manufacturers. }\end{array}$ & 3 & $30,0 \%$ & 7 & $70,0 \%$ & 0 & $\begin{array}{l}\text { Consensus } \\
\text { (DA) }\end{array}$ \\
\hline
\end{tabular}


Table 3: Results of the First Round of the Delphi Study (Cont.)

\begin{tabular}{|c|c|c|c|c|c|c|}
\hline \multirow{3}{*}{ Delphi Statements } & \multicolumn{5}{|c|}{ Answers } & \multirow{3}{*}{$\begin{array}{c}\text { Consensus } \\
\text { Status }\end{array}$} \\
\hline & \multicolumn{2}{|c|}{ Agree } & \multicolumn{2}{|c|}{ Disagree } & $\mathbf{U C}$ & \\
\hline & $\mathbf{N}$ & Rate & $\mathbf{N}$ & Rate & $\mathbf{N}$ & \\
\hline $\begin{array}{l}\text { S17.In the transportation of general } \\
\text { cargoes, it is more efficient to track and } \\
\text { trace the load flow between the } \\
\text { manufacturers and the port by port } \\
\text { businesses rather than manufacturers. }\end{array}$ & 3 & $30.0 \%$ & 7 & $70.0 \%$ & 0 & $\begin{array}{l}\text { Consensus } \\
\text { (DA) }\end{array}$ \\
\hline $\begin{array}{l}\text { S18. Long-term allocation of a part of the } \\
\text { storage area to other members of the } \\
\text { supply chain in ports that handle bulk and } \\
\text { general cargoes, and providing of } \\
\text { organization and stock management of } \\
\text { this area by the port business instead of } \\
\text { the cargo owners increases the supply } \\
\text { chain output. }\end{array}$ & 7 & $87.5 \%$ & 1 & $13 \%$ & 2 & $\begin{array}{c}\text { Consensus } \\
\text { (A) }\end{array}$ \\
\hline $\begin{array}{l}\text { S19. The safety of cargoes (Lashing and } \\
\text { securing) is at sufficient level during the } \\
\text { storage, transportation, and loading } \\
\text { processes of general cargoes at the port } \\
\text { area in the Aliağa Region. }\end{array}$ & 4 & $50.0 \%$ & 4 & $50 \%$ & 2 & $\begin{array}{l}\text { Second } \\
\text { Round } \\
\text { Applied }\end{array}$ \\
\hline $\begin{array}{l}\text { S20. Bulk and general cargo terminals are } \\
\text { required to provide value-added services } \\
\text { (packaging, quality control, maintenance, } \\
\text { repair, cargo tracking and tracing, } \\
\text { shipment support, etc.) as much as } \\
\text { container terminals. }\end{array}$ & 8 & $80.0 \%$ & 2 & $20 \%$ & 0 & $\begin{array}{c}\text { Consensus } \\
\text { (A) }\end{array}$ \\
\hline $\begin{array}{l}\text { S21. In the Aliağa Region, port } \\
\text { businesses that handle bulk and general } \\
\text { cargoes provide adequate value-added } \\
\text { services to meet the needs of port users. }\end{array}$ & 3 & $30.0 \%$ & 7 & $70 \%$ & 0 & $\begin{array}{l}\text { Consensus } \\
\text { (DA) }\end{array}$ \\
\hline
\end{tabular}

According to $66.7 \%$ of experts, operational efficiency is not more important than service effectiveness in bulk logistics (S11). Since there was no consensus, second round was applied to this statement. Service effectiveness is also important as well as operational efficiency in dry bulk logistics with the consensus rate of 100\% (S11.1). This showed that service dimension of dry bulk and general cargo terminals together with the service quality requirements has been neglected and a new perspective for 
focusing on service-related components of such terminals is highly needed. Road transportation infrastructure was considered sufficient in Aliağa Region according to $55.6 \%$ of the experts (S12), since no consensus was achieved, this statement was also re-formulated. According to second round, road transportation infrastructure should be developed with the consensus rate of $88.9 \%$ (S12.1). In addition to road transportation, all experts have agreed that railway infrastructure is not sufficient in the Aliağa Region (S13). According to comparison of these two transport modes in terms of efficiency of domestic transportation of dry bulk cargoes with short distances between manufacturers and dry bulk cargo terminals, road transportation was considered more efficient (S14). This is mostly due the availability of road transportation with developed infrastructure. Port businesses should pay attention to the organization of inland transportation activities as a service to increase efficiency according to $70 \%$ of experts (S15). In contrast to organization of inland transportation, it is less efficient to track and trace the cargo flow between manufacturers and port by port businesses in the transportation of dry bulk and general cargoes (S16, S17). According to $87.5 \%$ of experts; long-term allocation of a part of the storage area to other members of the supply chain in dry bulk and general cargo terminals and providing services regarding the organization and stock management by the port businesses increase the supply chain output (S18). According to 50\% of the experts; the safety of cargoes is at sufficient level during the storage, transportation, and loading processes of general cargoes at the port area in Aliağa Region, however no consensus has been achieved (S19). In the second round, all experts agreed that the port businesses should pay extra attention to the safety of cargoes (S19.1). According to $80 \%$ of experts, dry bulk and general cargo terminals are required to provide value-added services as much as container terminals (S20). Finally, port businesses that handle dry bulk and general cargoes do not provide adequate value-added services to meet the needs of port users in the Aliağa Region (S21). 
Table 4: Results of the Second Round of the Delphi Study

\begin{tabular}{|c|c|c|c|c|c|c|}
\hline \multirow{3}{*}{ Delphi Statements } & \multicolumn{5}{|c|}{ Answers } & \multirow{3}{*}{\begin{tabular}{|c|} 
Consensus \\
Status
\end{tabular}} \\
\hline & \multicolumn{2}{|c|}{ Agree } & \multicolumn{2}{|c|}{ Disagree } & \multirow{2}{*}{\begin{tabular}{|c|}
$\mathbf{U C}$ \\
$\mathbf{N}$ \\
\end{tabular}} & \\
\hline & $\mathbf{N}$ & Rate & $\mathbf{N}$ & Rate & & \\
\hline $\begin{array}{l}\text { S8.1. Terminals where are located in the } \\
\text { Aliağa Region should pay more attention } \\
\text { to technological development in order to } \\
\text { increase operational efficiency and } \\
\text { service quality. }\end{array}$ & 9 & $100.0 \%$ & 0 & $0.0 \%$ & 0 & $\begin{array}{l}\text { Consensus } \\
\text { (A) }\end{array}$ \\
\hline $\begin{array}{l}\text { S11.1. In dry bulk logistics, service } \\
\text { effectiveness (Flexibility, reliability) is } \\
\text { also important as well as operational } \\
\text { efficiency. }\end{array}$ & 7 & $100.0 \%$ & 0 & $0.0 \%$ & 2 & $\begin{array}{l}\text { Consensus } \\
\text { (A) }\end{array}$ \\
\hline $\begin{array}{l}\text { S12.1. Hinterland road transportation } \\
\text { infrastructure should be developed in the } \\
\text { Aliağa Region. }\end{array}$ & 8 & $88.9 \%$ & 1 & $11.1 \%$ & 0 & $\begin{array}{l}\text { Consensus } \\
\text { (A) }\end{array}$ \\
\hline $\begin{array}{l}\text { S19.1. The safety of cargoes (Lashing and } \\
\text { Securing) should be given importance } \\
\text { during the storage, transportation, and } \\
\text { loading processes of general cargoes at } \\
\text { the port area. }\end{array}$ & 9 & $100.0 \%$ & 0 & $0.0 \%$ & 0 & $\begin{array}{l}\text { Consensus } \\
\text { (A) }\end{array}$ \\
\hline
\end{tabular}

As mentioned at the section of questionnaire development, two open ended questions have been asked to participants. This paragraph includes evaluation of findings obtained from these open-ended questions. According to experts, most demanded value-added services in dry bulk and general cargo terminals are covered storage renting service to dry bulk cargoes since they are affected from natural/weather conditions, and open storage renting service to dry bulk cargoes which are not affected from natural/weather conditions. In contrast to lower prices of competing terminals, customers prefer terminals those providing these value-added services. Although price component is widely accepted as the most important factor in the competitiveness of seaports, it is seen that availability of value-added services are also considered critical and customers are willing to pay more for such services. In addition, packaging, lashing and securing, dunnage, supervision and inland transportation have been listed as the most demanded value-added services in dry bulk and general cargo terminals. According to an expert, valueadded services are mostly applied to project cargoes, but this process is not implemented effectively in Aliağa Region. In order to strengthen the 
position of dry bulk and general cargo terminals in the supply chain, one of the experts indicated that the port centric logistics activities should be provided. Thus, terminals that adapt to the port centric logistics system can act in coordination with supply chain strategies, and their logistical positions within the chains can turn into a center by focusing more on value-added services. Terminals can meet many logistical needs of the supply chain participants and increase their competitiveness with the service quality gained thanks to this transformation. In addition, two experts highlighted that the choice of well-educated and trained personnel rather than the ranker personnel to manage the supply chain processes in the terminals can strengthen the position of such terminals in the supply chain.

Although most of the findings could not be directly linked with the literature due to the fact that there are very limited studies concentrating on such topic in the literature and the study focuses on a very specific region, common findings were observed in the related literature on port business, supply chain management, and port centric logistics. Esmer (2010) pointed that ports and terminals are the nodes of the supply chain for an efficient logistics system. In addition, ports have become an integral part of the supply chain in management and coordination of material and information flow. Similar findings were found as a result of the study as bulk cargo terminals are one of the important nodes between raw material suppliers and manufacturers in supply chain, and also providing information flow between the terminals and the manufacturers is important in terms of supply chain efficiency. In addition, Chairany and Hidayatno (2019) stated that the ports that are integrated with the concept of port centric logistics become available to be the center of the supply chain by providing various value-added services which are integrated with the supply chain and can meet the needs of the chain. According to findings from the study, it has been determined that port businesses that handle bulk and general cargoes in the Aliağa Region do not provide adequate valueadded services to meet the need of chain and hence can not to be the central point of the supply chain. In other words, according to expert opinions, dry bulk and general cargo terminals in Aliağa Region do not have the necessary value-added service competency to meet their supply chain needs. As pointed in the related literature, it is mentioned in the recommendations section that these terminals should make up for this deficiency. Karataş Çetin (2011) mentioned value-added services at ports as; mainly loading/unloading, stuffing/unstuffing, bulk storage, tank storage, general storage, cold storage, distribution centers, quality control, repackaging, customization, assembly, testing, repair, reuse, safety and security activities, parking activities etc. In addition to related literature, the most demanded value-added services at dry bulk and general cargo 
terminals in Aliağa Region are packaging, lashing and securing, dunnage, supervision and inland transportation in accordance with the findings. Findings of the study are somewhat parallel to Balc1 et al. (2018)'s study who ranked dry bulk terminal selection criteria and asserted that damage/loss performance was ranked as the second determinative criteria in the selection of dry bulk terminals. Our findings also highlighted that safety of the cargoes should be considered well including loading, transportation and storage functions. However, in Balc1 et al. (2018)'s study responsiveness was in general ranked as the fifth important criterion as a criterion which is rather less important than cargo handling costs, damage and loss, location of terminal etc. In this study, service effectiveness including flexibility and responsiveness was considered important in value creation.

\section{CONCLUSIONS, LIMITATIONS RECOMMENDATIONS FOR FUTURE RESEARCH}

AND

The ports, which take place in the supply chains with the valueadded logistic services and activities they provide, serve as distribution centers considering the developments taking place in hinterland transportation. This study can be considered as an exploratory research to future studies related to dry bulk and general cargo terminals in the supply chain in terms of positions and roles of ports, and effectiveness and efficiency of the services. The role of dry bulk and general cargo terminals in the supply chain is mostly involved in the supply process of the chain because maritime transportation is suitable for the transportation of raw materials in bulk form, and general cargoes mostly consist of semi-finished products. Therefore, dry bulk and general cargo terminals have a role in the supply chain by not also transferring of these cargoes, but also providing value-added logistics services in addition to their core activities in order to meet the needs of the supply chain with collaboration and coordination.

The Delphi technique has been employed to determine the roles of dry bulk and general cargo terminals and to evaluate impacts of valueadded services to strengthen their positions in the supply chains for the Aliağa Region. Delphi study consists of eight main steps from development of research questionnaire to evaluation of findings, and data collection consists of two rounds that include port-supply chain related and port-logistics related statements. In order to evaluate the statements as consensus, the minimum rate has been conducted $70 \%$ in this study. The consensus has been reached for all the statements at the end of the second round. To the best of authors' knowledge, this research has originality on understanding and identifying the role of value-added services by 
considering supply-chain and logistics-based components from the perspective of dry bulk and general cargo terminals from the case of Aliağa Region. Although there is considerable research on container terminals from various perspectives such as supply chain orientation, port-centric logistics, value-added services etc, studies on dry bulk and general cargo terminals from the scope of logistics and supply chain management are quite limited.

There are some limitations of the study mostly due to the bottlenecks caused by COVID-19 pandemic during the data collection process. Hence, it was determined that face-to-face data collection posed a risk to both participants and the researchers, so that the data collection process was conducted by sending an online survey link to the participants via e-mail and LinkedIn accounts. Therefore, many potential participants could not provide sufficient feedback. Another limitation is that the study had to be completed in a certain time interval. Although sufficient data were available in the study, reaching more participants and collecting more data could not be achieved due to both limitations. Since the number of studies conducted in logistics and supply chain practices of dry bulk and general cargo terminals are scant in the current literature, authors had no specific checklist or guide to employ with regards to components and variables. Therefore, related literature on port businesses has been reviewed in order to obtain the components to be used in Delphi research. Another limitation is that the findings may not be generalized to other regions as well as countries.

Port of Aliağa is one of the leading ports in Turkey in terms of cargo handling statistics. Many of the port businesses in the Port of Aliağa are the part of the group companies of the industrial firms operating in the Aliağa Region. Thus, these port businesses have a role in the logistics of the industrial cargoes mostly in the region. The findings of the study showed that the existence of manufacturers and port businesses within the group of companies increases the integration and chain efficiency. These terminals have sufficient infrastructure, superstructure, equipment, and labor to meet the needs of chain participants and to serve other parties; but the road and railway transportation infrastructures in hinterland should be developed for effective and efficient inland transportation. Especially, the development of the inadequate railway connection in the region will ensure the growth of the logistics processes in hinterland transportation. Thus, the terminals will be involved in more supply chain processes and will develop more. In addition, although the road transportation is efficient at short distances, the railway connection will provide more efficient inland transportation at long distances.

In dry bulk and general cargo terminals, service effectiveness is important as well as operational efficiency. The use of technology will 
contribute to both of them, but terminals in the Aliağa Region should pay more attention to technological developments. Providing value-added services by port business will increase the service effectiveness, operational efficiency and supply chain output. However, these terminals have inadequate value-added services to meet the needs of the chain and they should pay more attention since dry bulk and general cargo terminals are required to provide value-added services as much as container terminals. The reason of inadequate value-added services may be due to the weak competition in the region since most of the terminals have guaranteed cargoes from their partners in the group of companies.

On the other hand, the supply stages of the chain is partly less at the forefront rather than the distribution stages of the supply chain in terms of logistics, which results in the position of the bulk and general cargo terminals not to be strong and competitive enough in the supply chain. The main logic behind this is that cost and speed are the main objectives of the supply chain systems. Bulk and general cargo logistics has a certain strength in terms of cost, but speed is not at the required level in the background in the supply stages of the chain because well-planned and high-volume inventory management eliminates the need for speed. Hence, speed is also against the nature of maritime transportation. When looking at the distribution processes of the chain, it is seen that both speed and cost are vital because downstream actors of the chain, like retailers and end users, have limited stock possibilities; and the liquidity of material flow is high at this stage. However, speed may also come to the fore in supply stages as a result of the fierce competition that may take place in the future. For example, nowadays in some of the supply chains, variables such as speed, cost and low inventory have great importance from beginning to end of the chain to the end with the use of just in time concept. Thus, bulk and general cargo terminals might be expected to strengthen their position in the supply chain in the coming years.

In conclusion, a supply chain concept exists in the region thanks to integration between terminals and manufacturers, but some shortcomings mentioned above prevent the supply chain processes to be carried out effectively and efficiently in the region. It is suggested to practitioners and decision makers for port businesses that the expansion of the inland transport network will enable the growth of the hinterland and increase the demand for port services. Thus, regional competitive advantage will be obtained, and the competition between terminals will probably increase in order to take share from the increasing demand. This competitive environment provides ground for overcoming shortcomings discussed in the study above and open ways to the development of terminals for both effective and efficient supply chain processes. 
These information and findings obtained with the case of Aliağa Region might be employed in future research aiming to determine the role of dry bulk and general cargo ports in the supply chain. As suggestions to the researchers for future studies, the use of other qualitative methods, such as interviews, can contribute to obtaining more detailed information from the supply chain actors. In addition, surveys can be conducted by employing the main variables discussed in the study on specific samples of port stakeholders. For instance, shipper-based or service provider-based surveys may provide fruitful outcomes for understanding the basic needs and requirements of such actors with regards to value-added services, operational efficiency and service effectiveness. Finally, addressing the studies, which aims to identify the role of ports in the supply chain, in ports that are suitable for both regional, intra-port, and inter-port competition, such as ports operated with landlord port ownership structure, can provide more efficient results.

\section{REFERENCES}

Alderton, P. (2008). Port Management and Operations. London: Informa.

Alghaffari S., Nguyen, H.O. \& Chen, P.S.L. (2018). Critical factors in organisational effectiveness: the case of Saudi Arabian seaports. Journal of Sustainable Development of Transport and Logistics, 3(2), 49- 65.

Altuntaş Vural, C., Göçer, A. \& Deveci, D.A. (2015). Türkiye konteyner limanlarında pazar yönlülük: itici güçler ve engeller. Dokuz Eylül Üniversitesi Denizcilik Fakültesi Dergisi. II. Liman Kongresi Özel Sayıs,, 117-152.

Arof, A.M., Mdhanafiah, R. \& Ooi, I.U.J. (2016). A Delphi Study on the Potential benefits and obstacles of interstate short sea shipping in Archipelagic Southeast Asia. International Journal of e-Navigation and Maritime Economy, 5, 97-110.

Atik, O. \& Cerit, G. (2008). Government support for sustainability of marine salvage services: a case for Turkey. In: Proceedings of IAME 2008 Conference. Dalian, China.

Babu, S., Pratap, S., Lahoti, G., Fernandes, K.J., Tiwari, M.K., Mount, M., Xiong, Y. (2015). Minimizing delay of ships in bulk terminals by simultaneous ship scheduling, stockyard planning and train scheduling. Maritime Economics and Logistics, 17, 464-492. 
Bal, K. \& Esmer, S. (2015). Sıvı kimyasal yük terminallerinde operasyon süreçleri üzerine bir değerlendirme. In: 2. Ulusal Liman Kongresi. Izmir, Turkey.

Balc1, G., Cetin, İ.B. \& Esmer, S. (2018). An evaluation of competition and selection criteria between dry bulk terminals in izmir. Journal of Transport Geography, 69, 294-304.

Barros, V.H., Costa, T.S., Oliviera, A.C.M., Lorena, L.A.N (2011). Model and heuristic for berth allocation in tidal bulk ports with stock level constraints. Computers \& Industrial Engineering, 60 (4), 606-613.

Behdani, B., Wiegmans, B. \& Roso, V. (2020). Port-hinterland transport and logistics: emerging trends and frontier research. Maritime Economics and Logistics, 22, 1-25.

Bichou, K. \& Gray, R. (2004). A Logistics and supply chain management approach to port performance measurement. Maritime Policy and Management, 31(1), 47-67.

Bichou, K. \& Gray, R. (2005). A Critical review of conventional terminology for classifying seaports. Transportation Research Part A: Policy and Practice, 39(1), 75-92.

Brett, V. and Roe, M. (2010). The potential for the clustering of the maritime transport sector in the Greater Dublin Region. Maritime Policy \& Management, 37(1), 1-16.

Carbone, V. \& De Martino, M. (2003). The changing role of ports in supply-chain management: an empirical analysis. Maritime Policy and Management, 30(4), 305-320.

Chairany, N. \& Hidayatno, A. (2019). Coordination in port-centric logistics and contractual agreement: preliminary evidence of a literature review. In: 2019 the 6th International Conference on Frontiers of Industrial Engineering, London, United Kingdom.

Chen, Z. \& Pak, M. (2017). A Delphi analysis on green performance evaluation indices for ports in China. Maritime Policy \& Management, 44 (5), 537-550. 
Creswell, J.W. (2005). Educational Research: Planning, Conducting, and Evaluating Quantitative and Qualitative Research. Upper-Saddle River, NJ: Pearson Education.

Czinkota, M.R. and Ronkainen, I.A. (1997). International business and trade in the next decade: report from a delphi study. Journal of International Business Studies, 28 (4), 827-844.

Da Cruz, M.R.P., Ferreria, J.J., Azevedo, S.G. (2013). Key factors of seaport competitiveness based on the stakeholder perspective: an analytic hierarchy process (AHP) model. Maritime Economics and Logistics, 15(4), 416-443.

Dalkey, N. \& Helmer, O. (1963). An experimental application of the delphi method to the use of experts. Management Science, 9(3), 458-467.

de Leòn, A.D., Lalla-Ruiz, E., Melián-Batista, B., Moreno-Vega, M. (2017). A machine learning-based system for berth scheduling at bulk terminals. Expert Systems with Applications, 87, 170-182.

De Martino, M. \& Morvillo, A. (2008). Activities, resources and interorganizational relationships: key factors in port competitiveness. Maritime Policy and Management, 35(6), 571-589.

Denktaş Şakar, G. \& Marlow, P. (2009). An organisational buying perspective for multimodal transport: a Delphi study for Turkey. In: Proceedings of IAME 2009 Conference, Copenhagen, Denmark.

Denktaş Şakar, G., Yıldırım, E. \& Mansuroğlu, E. (2018). Value creation in project cargo logistics: a Delphi study. Journal of ETA Maritime Science, 6(3), 255-274.

Deveci, D.A. \& Cerit, A.G. (2007). Competition and conflict in distribution channels of combined transport services. In: 12. National Marketing Congress. Turkey, 18-20 October 2007.

Dinwoodie, J., Landamore, M., Rigot-Muller, P. (2014). Dry bulk shipping flows to 2050: delphi perceptions of early career specialists. Technological Forecasting and Social Change, 88, 64-75.

DTGM (Deniz Ticareti Genel Müdürlüğü). (2020). Yük İstatistikleri, https://atlantis.udhb.gov.tr/istatistik/istatistik_yuk.aspx, Date Accessed: 20.03.2020. 
Emiroğlu, Ç. \& Çaylan, D. O. (2014). The importance of strategic leadership for port management: a Delphi research on top managers of Turkish private ports. Journal of Global Strategic Management, 8(2), 516.

Ernst, A.T., Oğuz, C., Singh, G., Tharkhani, G. (2017). Mathematical models for the berth allocation problem in dry bulk terminals. Journal of Scheduling, 20, 459-473.

Eroğlu, İ. \& Bozyiğit, R. (2013). Aliağa liman1. Marmara Coğrafya Dergisi, 28, 81-116.

Esmer, S. (2010). Konteyner Terminallerinde Lojistik Süreçlerin Optimizasyonu ve Bir Simülasyon Modeli. Doktora Tezi, Dokuz Eylül Üniversitesi Ssoyal Bilimler Enstitüsü, İzmir.

Esmer, S. \& Karataş Çetin, Ç. (2016). Liman İşletme Yönetimi, in A.G. Cerit, A. Deveci, \& S. Esmer (Eds), Denizcilik İsletmeleri Yönetimi. İstanbul: Beta Basım Yayım Dağıtım A.Ş.

Fadda, E.A. (1996). Brazilian coastal shipping in 2010: qualitative scenarios through the application of the delphi and scenario writing methods. PhD Thesis, Cardiff University.

Fink, A., Kosecoff, J., Chassin, M.R. \& Brook, R.H. (1984). Consensus methods characteristics and guidelines for use. American Journal of Public Health, 74(9).

Fontana, A. \& Frey, J. (1994). Interviewing: The Art of Science, in N. Denzin, \& Y. Lincoln (Eds.), Handbook of Qualitative Research. Thousand Oaks, CA: Sage Publication, Inc.

Frankel, E., Cooper, J., Chang, Y.W., Tharakan, G. (1984). Bulk Shipping and Terminal Logistics. Washington: World Bank Publications.

Garcia-Alonso, L., Monios, J. \& Vallejo-Pinto, J.Á. (2017). Port competition through hinterland accessibility: the case of Spain. Maritime Economics \& Logistics, 21, 258-277.

Goodrich, N.M. (1982). A Profile of the Competent Nursing Administrator. UMI Research Press. Ann Arbor, Ml. 
Gordon, T.J. (1994). The Delphi method. Futures Research Methodology, 2(3), 1-30.

Göçer, A., Altuntas Vural, C. \& Deveci, D.A. (2019). Drivers and barriers against market orientation: a study of Turkish container ports. Maritime Economics and Logistics, 21 (2), 278-305.

Güneş, H. \& Esmer, S. (2016). Liman merkezli lojistik: Ege Bölgesi için bir değerlendirme. Journal of ETA Maritime Science. 4(4), 303-316.

Haralambides, H.E. (2017). Globalization, public sector reform, and the role of ports in international supply chains. Maritime Economics and Logistic, 19 (1), 1-51.

Hasson, F., Keeney, S. \& McKenna, H. (2000). Research guidelines for the Delphi survey technique. Journal of Advance Nursing, 32(4), 1008-1015.

Hu, D. and Yao, Z. (2012). Stacker-reclaiming scheduling in a dry bulk terminal. International Journal of Computer Integrated Manufacturing, 25 (11), 1047-1058.

Hsu, C.C. and Sandford, B.A. (2007). The Delphi technique: making sense of consensus. Practical Assessment, Research, and Evaluation, 12(10), 18.

Islam, D.Z., Dinwoodie, J. \& Roe, M. (2006). Promoting development through multimodal freight transport in Bangladesh. Transport Reviews, 26(5), 571-591.

Karataş Çetin, Ç. \& Cerit, A.G. (2010) Organizational effectiveness at seaports: a systems approach. Maritime Policy \& Management, 37 (3), 195-219.

Karataş Çetin, Ç. (2011). Limanlarda örgütsel değişim ve değer zinciri sistemlerinde etkililik analizi. Doktora Tezi, Dokuz Eylül Üniversitesi Sosyal Bilimler Enstitüsü, İzmir.

Karataş Çetin, Ç. \& Cerit, G. (2014). Organisational change in ports and analysis of effectiveness in value chain systems: a survey research. Işsletme Fakültesi Dergisi, 15 (2), 83-115.

Kinnear, T.C. \& Taylor, J.R. (1996). Marketing Research: An Applied Approach. New York, McGraw-Hill. 
Lee, T., Yeo, G.\& Thai, V.V. (2014). changing concentration ratios and geographical patterns of bulk ports: the case of the Korean West Coast, Asian Journal of Shipping and Logistics, 30 (2), 155-173.

Lodewijks, G., Schott, D.L. \& Ottjes, J.A. (2007). Modern dry bulk terminal design. Bulk Solids Handling, 27(6), 364-376.

Loo, R. (2002). The Delphi method: a powerful tool for strategic management and policing. An International Journal of Police Strategies \& Management, 25(4), 762-769.

Ludwig, B. (1997). Predicting the future: have you considered using the delphi methodology. Journal of Extension, 35(5), 1-4.

Mangan, J., Lalwani, C. \& Fynes, B. (2008). Port centric logistics. The International Journal of Logistics Management, 19(1), 29-41.

Min, H. \& Jun, C.Y. (2014). Public-private partnerships for the development of port hinterlands and their ramifications for global supply chain management. Maritime Economics and Logistics, 16(3), 250-275.

Murphy, M.K., Black, N.A., Lamping, D.L., McKee, C.M., Sanderson, C.F.B., Askham, J. \& Marteau, T. (1998). Consensus development methods, and their use in clinical guideline development. Health Technology Assessment, 2(3).

Notteboom, T. \& Winkelmans, W. (2004). FR-WP1: Overall Market Dynamics and Their Influence on the Port Sector, in Factual Report on the European Port Sector. European Sea Ports Organisation, pp. 4-60. Brussels: ESPO.

Ojala, L., Kersten, W. \& Lorentz, H. (2013). Transport and logistics developments in the Baltic Sea Region until 2025. Journal of East-West Business, 19 (1-2), 16-32.

Paixao, A.C. \& Marlow, P.B. (2003). Fourth generation ports - a question of agility? International Journal of Physical Distribution and Logistics Management, 33(4), 355-376.

Panayides, Ph. M. (2006). Maritime logistics and global supply chains: towards a research agenda. Maritime Economics and Logistics, 8(2), 3-18. 
Panayides, Ph. M. \& Song, D.W. (2007). Development of a measurement instrument for port supply chain orientation. In: 2007 IAME Annual Conference. Athens, Greece.

Pettit, S.J. \& Beresford, A.K.C. (2009). Port development: from gateways to logistics hubs. Maritime Policy and Management, 36(3), 253-267.

Polit D.F. and Hungler B.P. (1997) Essentials of Nursing Research: Methods, Appraisal and Utilisation. New York: Lippincott.

Robinson, R. (2002). Ports as elements in value-driven chain systems: the new paradigm. Maritime Policy and Management, 29(3), 241-255.

Rodrigue, J.P. (2020). The Geography of Transport Systems. New York: Routledge.

Rowe, G. \& Wright, G. (1999). The Delphi technique as a forecasting tool: issues and analyses. International Journal of Forecasting, 15, 353-375.

Rushton, A., Oxley, J. \& Croucher, P. (2000). The Handbook of Logistics and Distribution Management. London: Kogan Page.

Saldanha, J. \& Gray, R. (2002) The Potential for British coastal shipping in a multimodal chain. Maritime Policy \& Management, 29(1), 77-92.

Sayareh, J. \& Ahouei, V.R. (2013). Failure mode and effect analysis for reducing the delays of cargo handling operations in marine bulk terminals. Journal of Maritime Research, 10 (2), 43-50.

Scapolo, F.\& Miles, I. (2006). Eliciting experts knowledge: a comparison of two methods. Technological Forecasting and Social Change,73, 679704.

Schott, D.L. \& Lodewijks, G. (2007). Analysis of dry bulk terminals: chances for exploration. Particle and Particle Systems Characterization, 24, 375-380.

Skulmoski, G., Hartman, F. \& Krahn, J. (2007). The Delphi method for graduate research. Journal of Information Technology Education: Research, 6 (1), 1-21. 
Song, D-W., \& Lee, P. (2009). Maritime logistics in the global supply chain. International Journal of Logistics: Research and Applications, 12(2), 83-84.

Song, D-W., \& Panayides, Ph. M. (2008). Global Supply chain and port/terminal: integration and competitiveness. Maritime Policy and Management, 35(1), 73-87.

Song, D-W., \& Panayides Ph. M. (2012). Maritime logistics: A Complete Guide to Effective Shipping and Port Management. UK: Kogan Page.

Stank, T.P., Keller, S.B. \& Daugherty, P.J. (2001). Supply chain collaboration and logistical service performance. Journal of Business Logistics, 22(1), 29-48.

Tezcan, Ö. \& Kuleyin, B. (2019). Academicians' viewpoint on port managers' prior competencies in terms of environmental sustainability performance of container port enterprises in Turkey. Journal of ETA Maritime Science, 7(4), 280-292.

Tuna, O. \& Arabelen, G. (2016). Deniz Ulaştırma Lojistiği, in A. G. Cerit, A. Deveci, \& S. Esmer (Eds), Denizcilik İşletmeleri Yönetimi. İstanbul: Beta Basım Yayım Dă̆ııım A.Ş.

Turoff, M. (1970). The design of a policy Delphi. Technological Forecasting and Social Change, 2(2), 149-171.

Türklim (Türkiye Liman İşletmecileri Derneği). (2018). Türk limancıllk sektörü 2018 raporu. Port Operators Association of Turkey.

UNCTAD (United Nations Conference on Trade and Development) (2004). Assessment of A Seaport Land Interface: An Analytical Framework. Report by the UNCTAD Secretariat.

UNESCAP \& KMI (United Nations Economic and Social Commission for Asia and the Pacific and Korean Maritime Institute) (2005). Free trade zone and port hinterland development. New York: United Nations Publications.

Ünsal, O. \& Oğuz, C. (2019). An exact algorithm for integrated planning of operations in dry bulk terminals. Transportation Research Part E: Logistics and Transportation Review, 126, 103:121. 
Van Vianen, T., Ottjes J. \& Lodewijks., G (2014). Simulation-based determination of the required stockyard size for dry bulk terminals. Simulation Modelling Practice and Theory, 42, 119-128.

Verhoeven, P. (2010). A review of port authority functions: towards a renaissance? Maritime Policy and Management, 37(3), 247-270.

Von der Gracht, H.A. (2012). Consensus measurement in Delphi studies. Technological Forecasting and Social Change, 79, 1525-1536.

Williams, P.L. and Webb, C. (1994). The Delphi technique: a methodological discussion. Journal of Advanced Nursing, 19(1), 180-186.

Yang, D., Wang, K.Y., Xu, H., Zhang, Z. (2017). Path to a multilayered transshipment port system: how the Yangtze River bulk port system has evolved. Journal of Transport Geography, 64, 54-64.

Zhang, X. \& Roe, M. (2019). Maritime Container Port Security. USA and European Perspectives. Switzerland: Springer AG. 